\title{
Climate Change: A CALL FOR ADAPTATION AND MITIGATION STRATEGIES
}

\author{
I. Chaubey, D. D. Bosch, R. Muñoz-Carpena, R. Daren Harmel, \\ K. R. Douglas-Mankin, A. P. Nejadhashemi, \\ P. Srivastava, A. Shirmohammadi
}

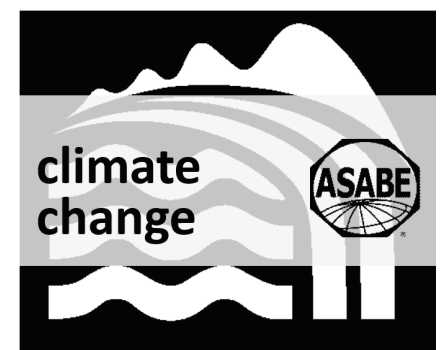

\begin{abstract}
Projected climate change is expected to substantially affect crop and livestock production, and water availability and quality. Concomitantly, the agricultural community is faced with a challenge of increasing food production by more than $70 \%$ to meet demand from global population increase by the mid-21st century. This article introduces a Special Collection on Climate Change and reviews principal findings from nine articles drawn from papers presented at the 2015 ASABE 1st Climate Change-Adaptation and Mitigation Symposium. Studies present simulations of crop and livestock production-system adaptations to climate change scenarios; impacts of climate change scenarios on water resources, soil erosion and nonpoint-source pollutant source areas; regional assessment of climatic shifts; and mitigation of greenhouse gas emissions from livestock production. Articles span regional issues across the U.S., southern Asia, and Brazil. These research articles clearly indicate that climate variability and change can negatively impact food production and water resources, and that innovative strategies are needed to mitigate those negative impacts.
\end{abstract}

Keywords. Adaptation, Agricultural production, Climate change, Mitigation, Water.

$\mathrm{T}$ The American Society of Agricultural and Biological Engineers (ASABE) organized the 1st Climate Change Symposium-Adaptation and Mitigation in May 2015 in Chicago to address complex questions related to how agriculture and watershed management can mitigate and adapt to climate change impacts. The symposium covered topics related to adaptation strategies and benefits of

Submitted for review in October 2016 as manuscript number NRES 12138; approved for publication as part of the Climate Change collection by the Natural Resources \& Environmental Systems Community of ASABE in December 2016.

Mention of company or trade names is for description only and does not imply endorsement by the USDA. The USDA is an equal opportunity provider and employer.

The authors are Indrajeet Chaubey, ASABE Member, Professor, Department of Earth, Atmospheric, and Planetary Sciences and Department of Agricultural and Biological Engineering, Purdue University, West Lafayette, Indiana; David D. Bosch, ASABE Fellow, Research Hydrologist, USDA-ARS Southeast Watershed Research Laboratory, Tifton, Georgia; Rafael Muñoz-Carpena, ASABE Fellow, Professor, Department of Agricultural and Biological Engineering, University of Florida, Gainesville, Florida; R. Daren Harmel, ASABE Member, Director, USDA-ARS Center for Agricultural Resources Research, Fort Collins, Colorado; Kyle R. Douglas-Mankin, ASABE Member, Hydrologist, U.S. Geological Survey, New Mexico Water Science Center, Albuquerque, New Mexico; A. Pouyan Nejadhashemi, ASABE Member, Associate Professor, Department of Biosystems and Agricultural Engineering, Michigan State University, East Lansing, Michigan; Puneet Srivastava, ASABE Member, Professor, Department of Biosystems Engineering, Auburn University, Auburn, Alabama; Adel Shirmohammadi, ASABE Fellow, Professor, Associate Dean for Research and Agricultural Experiment Station, University of Maryland, College Park, Maryland. Corresponding author: Indrajeet Chaubey, 550 Stadium Mall Drive, Purdue University, West Lafayette, IN 47907; phone: 7654-494-3258; email: ichaubey@purdue.edu. adaptation, mitigation, ecosystem health and services, agroecosystem sustainability, climate change modeling and interface of climate models with the agroecosystem models, uncertainty and complexity, and water resource policy. This symposium had more than 150 oral or poster presentations and was attended by more than 160 participants. This Special Collection in this issue includes nine studies that were presented at the symposium. These studies cover a wide range of topics related to climate variability and change, mitigation and adaptation for agricultural production, water availability, and water quality management.

Recent increases in global temperature, prolonged wet and dry hydroperiods, and increased frequency and duration of extreme events including droughts and floods have been attributed to both natural climate variability and human-induced climate change that is modulating climate variability (Solomon et al., 2007). The 2014 U.S. National Climate Assessment report recognizes that effects of human-induced climate change are experienced in every corner of the United States, with water growing scarcer in dry regions, torrential rains increasing in wet regions, heat waves becoming more common and more severe, wildfires worsening, and forests dying under assault from heat-loving insects (Walsh et al., 2014). Average temperature in the U.S. has increased between $0.7^{\circ} \mathrm{C}$ to $1.1^{\circ} \mathrm{C}$ since 1895 with most of the increase since 1970. Along with the rise in temperature, climate change is projected to alter the global precipitation cycle, leading to variation in the spatial and temporal distribution of precipitation (Bates et al., 2008). In dry regions, climate change is projected to increase the frequency of meteorological, agricultural, and hydrological droughts (Jiménez Cisneros et al., 2014). In addition, climate change is projected to 
accelerate the melting of ice and snow cover, increase sea levels, change soil moisture, and change surface runoff and groundwater recharge. Surface runoff, which constitutes the majority of surface water resources, is not only sensitive to changes in precipitation but also to short-term rainfall distribution and intensity (Carter and Parker, 2009). Reduced precipitation, accompanied by increased evapotranspiration, would lead to increased drought risks, while heavy precipitation may lead to increased flooding risks. In glacier-dominated regions, accelerated melting of the glaciers would increase streamflow in the short run, but decrease flow in the long run (Hepworth and Goulden, 2008).

Climate change and variability impacts groundwater directly by altering groundwater replenishment and indirectly through groundwater use, which can be further impacted by land-use changes (Taylor et al., 2013). Groundwater recharge is generally projected to increase in areas where surface runoff is projected to increase; however, rainfall intensity may modify the fraction of surface runoff that recharges groundwater (Kundzewicz and Doell, 2009; Jiménez Cisneros et al., 2014). In coastal areas, there is concern that rise in sea level would exacerbate seawater intrusion of fresh groundwater resources (Werner et al., 2012). Groundwater generally is less sensitive to short-term climate variability; however, shallow aquifers may exhibit increased salinity or may even dry up due to increased evapotranspiration (Kundzewicz et al., 2007; Calow and MacDonald, 2009; Bonsor et al., 2010). Changes in these hydrological components will impact the quality and quantity of surface and groundwater resources, thereby increasing the competition among agricultural, ecosystems, settlements, industry, and energy sectors (Jiménez Cisneros et al., 2014; Delpla et al., 2009).

Climate change is projected to negatively impact crops in tropical latitudes due to greater moisture and heat stress and declining growing season length, but positively impact crops in high-latitude locations due to increased temperature and growing season length, although associate increases in temperature and moisture stress may also increase interannual crop variability (Porter et al., 2014). Heat stress during development and flowering stages leads to suppressed plant growth, reduced photosynthesis and shortened crop life, which may lead to poor crop yield and quality (Stone, 2001; Lobell and Gourdji, 2012; Bita and Gerats, 2013). Water stress results in a shortened reproduction stage, reduced photosynthesis rate, overheating, and increased pollen sterility (Barnabás et al., 2008; Alqudah et al., 2011). The impacts of climate change will be most severe in rainfed systems, where annual agricultural output depends on seasonal weather patterns. As such, in rainfed agricultural systems, lower agricultural production is not due to a lower annual rainfall, but due to the uneven distribution of rainfall (Barron et al., 2003). Farmers have already felt the impacts of climate change in the form of increased temperatures, decreased precipitation, shifted rainy-season onset, and increased short-term dry spells (Paavola, 2008; Lema and Majule, 2009; Mongi et al., 2010).

Droughts and heat waves during critical crop growth stages may also make landscapes increasingly vulnerable to environmental degradation and losses of sediment and nutrients. A review of climate-change impacts on soil erosion (Nearing et al., 2004) concluded the amount of erosion may increase by 1.7 times the future, climate-induced increase in annual rainfall. The degradation of water resources can be worsened with unfavorable sequences of extreme events, such as winter drought followed by spring floods, which can result in substantial losses of soil, nutrients, and fertilizers applied to agricultural fields and creating water quality problems, particularly in agricultural watersheds, and reduction in food production (Parry et al., 2007; Sheshukov et al., 2011).

Considering the negative impacts of climate change, we must develop adaptation strategies to cope with existing impacts while developing mitigation strategies to reduce future impacts. These strategies must work synergistically with the best management practices (BMPs) that are commonly applied to mitigate impacts of anthropogenic activities, such as agriculture and industry, on natural systems (Woznicki and Nejadhashemi, 2014). BMPs include both structural and management operations that aim to help regulate water quality and quantity and improve the condition of the natural environment (USGS, 2015). However, changes in temperature and precipitation caused by climate change can lead to reduced BMP effectiveness (Woznicki et al., 2011; Woznicki and Nejadhashemi, 2012; Bosch et al., 2014; Woznicki and Nejadhashemi, 2014; Renkenberger et al., 2015). In general, BMPs that utilized plants, such as native grass or cover crops, that produced the greatest reduction in sediment and nutrient loading, were found to be more sensitive to climate change (Chaubey et al., 2010; Woznicki et al., 2011; Bosch et al., 2014; Renkenberger et al., 2015). However, BMPs that utilized structural changes and management operations, such as no tillage and porous gully plugs, that produced lower reductions in sediment and nutrient loading, were found to be less sensitive to climate change (Chaubey et al., 2010; Woznicki et al., 2011; Woznicki and Nejadhashemi, 2012). This results in an overall decrease in BMP effectiveness as the climate continues to change. Furthermore, scenarios considering more-extreme future climate scenarios indicated greater loss of BMP effectiveness (Chaubey et al., 2010; Woznicki and Nejadhashemi, 2014; Renkenberger et al., 2015). In addition to this loss in effectiveness, future climate scenarios indicated an increase in surface-water flows, sediment loads, and nutrient loads, which would result in greater degradation of the ecosystems (Chaubey et al., 2010; Woznicki et al., 2011; Bosch et al., 2014). In order to combat this increase in degradation and loss in efficiency, additional BMPs will be required to maintain or improve current ecosystem conditions in the future and to mitigate climate change impacts.

\section{Content of the Climate Change COLleCtion}

In this introductory article, we highlight the major findings from nine papers presented at the symposium and published in this Collection. A summary of the results from these studies is presented in table 1 .

Climate change impacts can have important implications in many developing countries. Anandhi et al. (2016) analyze outputs from 36 General Circulation Models (GCMs) in south Asia and report a high variability in future precipitation 
Table 1. Summary of articles included in the 2016 ASABE Climate Change Special Collection.

\begin{tabular}{|c|c|c|c|c|}
\hline Authors & $\begin{array}{l}\text { Topic } \\
\text { Focus }\end{array}$ & Region & $\begin{array}{l}\text { Climate Model(s) } \\
\text { Used }^{[\mathrm{a}]}\end{array}$ & Title \\
\hline $\begin{array}{l}\text { Myoung, B., Kim, S. H., } \\
\text { Kim, J., Kafatos, M.C. }\end{array}$ & $\begin{array}{l}\text { Trans. } A S A B E \quad \text { Adaptation } \\
\text { 59(6): } 1759-1769\end{array}$ & $\begin{array}{l}\text { Southwestern } \\
\text { U.S. }\end{array}$ & NARR & $\begin{array}{l}\text { Regional variations of optimal sowing dates of maize } \\
\text { for the Southwestern United States }\end{array}$ \\
\hline $\begin{array}{l}\text { Kim, S. H., Myoung, B., Stack, } \\
\text { D. H., Kim, J., Kafatos, M. C. }\end{array}$ & $\begin{array}{l}\text { Trans. } A S A B E \quad \text { Adaptation } \\
59(6): 1745-1757\end{array}$ & $\begin{array}{l}\text { Southwestern } \\
\text { U.S. }\end{array}$ & NARR & $\begin{array}{l}\text { Sensitivity of maize yield potential to regional climate in } \\
\text { the Southwestern United States }\end{array}$ \\
\hline $\begin{array}{l}\text { Anandhi, A., Omani, N., } \\
\text { Chaubey, I., Horton, R., } \\
\text { Bader, D., Nanjundiah, R. S. } \\
\end{array}$ & $\begin{array}{l}\text { Trans. } A S A B E \quad \text { Assessment } \\
\text { 59(6): } 1715-1732 .\end{array}$ & Southern Asia & $\begin{array}{l}\text { CMIP5 (35 GCMs); } \\
\text { RCP4.5 and } 8.5 \\
\text { emission scenarios }\end{array}$ & $\begin{array}{l}\text { Synthetic scenarios from CMIP5 model simulations for } \\
\text { climate change impact assessments in managed ecosystems } \\
\text { and water resources: Case study in south Asian countries }\end{array}$ \\
\hline $\begin{array}{l}\text { Resende, N. C., Miranda, J. H., } \\
\text { Chou, S. C., Cooke, R. A. }\end{array}$ & $\begin{array}{l}\text { Trans. } A S A B E \quad \text { Adaptation } \\
\text { 59(6): } 1783-1790\end{array}$ & $\begin{array}{l}\text { Campinas, } \\
\text { Brazil }\end{array}$ & $\begin{array}{l}\text { HadCM3; A1B } \\
\text { emission scenario }\end{array}$ & $\begin{array}{l}\text { Regional climate changes on drainage systems: Effects on } \\
\text { corn productivity and profitability in Campinas, Brazil }\end{array}$ \\
\hline Sharda, V., Srivastava, P. & $\begin{array}{l}\text { Trans. } A S A B E \quad \text { Adaptation } \\
\text { 59(6): } 1733-1744\end{array}$ & $\begin{array}{l}\text { Southeastern } \\
\text { U.S. }\end{array}$ & $\begin{array}{l}\text { CWDI forecast } \\
\text { based on IRI ENSO } \\
\text { forecast ( } 22 \text { models })\end{array}$ & $\begin{array}{l}\text { Value of ENSO-forecasted drought information for the } \\
\text { management of water resources of small to mid-size } \\
\text { communities. }\end{array}$ \\
\hline $\begin{array}{l}\text { Rotz, C. A., Skinner, R. H., } \\
\text { Stoner, A. M. K., Hayhoe, K. }\end{array}$ & $\begin{array}{l}\text { Trans. } A S A B E \quad \text { Mitigation, } \\
\text { 59(6): } 1771-1781 \text { Adaptation }\end{array}$ & $\begin{array}{l}\text { New York, } \\
\text { U.S. }\end{array}$ & $\begin{array}{l}9 \text { GCMs; RCP4.5 } \\
\text { and } 8.5 \text { emission } \\
\text { scenarios }\end{array}$ & $\begin{array}{l}\text { Evaluating greenhouse gas mitigation and climate } \\
\text { change adaptation in dairy production using farm } \\
\text { simulation }\end{array}$ \\
\hline Oliver, J. P., Schilling, J. S. & $\begin{array}{l}\text { Trans. } A S A B E \quad \text { Mitigation } \\
\text { 59(6): } 1791-1801\end{array}$ & NA & NA & $\begin{array}{l}\text { Capture of methane by fungi: Evidence from lab-scale } \\
\text { biofilter and chromatographic isotherm studies }\end{array}$ \\
\hline $\begin{array}{l}\text { Garbrecht, J. D., Nearing, M. } \\
\text { A., Zhang, J. X. C., } \\
\text { Steiner, J. L. }\end{array}$ & $\begin{array}{l}\text { Appl. Eng. Agric. Adaptation } \\
\text { 32(6): } 833-846\end{array}$ & $\begin{array}{l}\text { Oklahoma, } \\
\text { U.S. }\end{array}$ & $\begin{array}{l}10 \text { GCMs; RCP } 4.5 \\
\text { and } 8.5 \text { emission } \\
\text { scenarios }\end{array}$ & $\begin{array}{l}\text { Uncertainty of climate change impacts on soil erosion } \\
\text { from cropland in central Oklahoma }\end{array}$ \\
\hline $\begin{array}{l}\text { Renkenberger, J., Montas, H., } \\
\text { Leisnham, P., Chanse, V., } \\
\text { Shirmohammadi, A., Sadeghi, } \\
\text { A., Brubaker, K., Rockler, A., } \\
\text { Hutson, T., Lansing, D. }\end{array}$ & $\begin{array}{l}\text { Trans. } A S A B E \quad \text { Adaptation } \\
\text { 59(6): } 1803-1819\end{array}$ & $\begin{array}{l}\text { Maryland, } \\
\text { U.S. }\end{array}$ & $\begin{array}{l}\text { GFDL CM2.1; B1, } \\
\text { A1B, A2 emission } \\
\text { scenarios }\end{array}$ & $\begin{array}{l}\text { Climate change impact on critical source area } \\
\text { identification in a Maryland watershed }\end{array}$ \\
\hline
\end{tabular}

change ranging from a decrease of $23 \%$ to an increase of $52 \%$ during non-monsoon periods. Temperature is expected to rise by $0.8 \%$ to $2.1 \%$ and will accelerate glacial retreat resulting in increased flooding and conversion of many perennial rivers to seasonal rivers. Reduced baseflow would negatively affect groundwater recharge and would further lead to groundwater decline affecting water availability for agricultural, urban, and industrial uses. Prolonged droughts can have devastating impacts on crop production, water availability for agricultural, domestic, and industrial use, and may result in severe economic losses.

Sharda and Srivastava (2016) assert that use of seasonal to inter-annual climate forecasts in water management decision-making is lacking. Using a case study in the southeast U.S., they show that small to medium-size municipalities can save both water and money by using climate (drought) forecasts and sound water (drought) management plans. The authors demonstrate that water-use restrictions are effective at reducing adverse impacts of drought when timed well with climate forecasts. Similarly, the authors of this article believe that better use of climate projections can not only help society mitigate the negative consequences of climate change, but also save money.

Several studies have reported adverse impacts of climate change on crop production. Kim et al. (2016) and Myoung et al. (2016) show that, in the southwestern U.S., corn production may be significantly affected by climate change, and the sowing dates for corn may need to be adjusted to achieve high yields. Based on simulations of past climate data using the Agricultural Production System Simulator (APSIM) model, Myoung et al. (2016) show that climate drivers can substantially affect corn yields, with potential yields being most sensitive to daily maximum and minimum temperatures. Extremely hot conditions in peak growing season and extremely low temperatures in spring may substantially decrease corn yields. A similar reduction in corn yield is also demonstrated for the New York region by Rotz et al. (2016) and the Campinas Region in Brazil by Resende et al. (2016). However, an increase in forage yield was reported for the New York region. Early planting may be necessary in low elevation warm regions to avoid yield reduction due to high temperature stress in the summer. In high elevation areas, warmer spring temperatures may enable early sowing and longer growing seasons may potentially increase crop yield. In Brazil, changes to current drainage practices are suggested as an adaptation practice to maintain yields under climate change conditions.

Methane emission from livestock production may account for 35 to $40 \%$ of global anthropogenic methane emission (Jacobson et al., 2011). An effective climate-change mitigation strategy must include reduction in emission of greenhouse gases (GHGs), including methane. Oliver and Schilling (2016), using a lab-scale biofilter, show that several fungal species are capable of capturing methane from livestock operations. The authors conclude that GHG emission from livestock operations can be considerably mitigated. Rotz et al. (2016) show that in dairy production systems, warmer temperatures will increase volatile losses of ammonia nitrogen. They also show that increase in precipitation will increase nutrient runoff losses to surface waters. The authors show that with appropriate adaptation strategies, annual farm profitability may increase by approximately $\$ 100 /$ cow. However, under high-emission scenarios, annual profitability may become highly volatile and may result in an overall decrease of $\$ 10 /$ cow.

Best management practices work best when they are implemented in critical source areas that export disproportionately large amounts of nonpoint-source pollutants or in the 
areas where they can be most effective. Renkenberger et al. (2016) show that under projected climate change scenarios, critical source areas for runoff, sediment, and nutrients will more than triple compared to current climate conditions in the Chesapeake Bay watershed, going from $21 \%$ of watershed area under current climate to between $70 \%$ for the B1 (low) emissions scenario to $81 \%$ for the A2 (high) emissions scenario. Under the projected climate change conditions in the northeast U.S., new BMPs will have to be implemented, in addition to current BMPs, to meet water-quality goals.

In evaluating climate change impacts on BMP effectiveness, it is important to consider various sources of uncertainty. Garbrecht et al. (2016) have evaluated uncertainties due to multiple emission scenarios, choice of climate models, and storm intensification alternatives. The authors show that irrespective of the choice of emission scenario or climate model, soil erosion is predicted to increase in the future. The authors argue that "assessment of future effectiveness of conservation practices must not only consider the inherent uncertainty associated with the realization of a future outcome, but also the uncertainty due to imperfect prediction tools."

\section{SUMMARY AND CONCLUSIONS}

The ASABE 1st Climate Change Symposium-Adaptation and Mitigation was organized to initiate an interdisciplinary dialogue to help researchers, policy makers, government agencies, and other stakeholder groups relate to mitigation and adaptation strategies for maintaining and increasing agricultural production while curtailing the negative impacts of climate change. Given the scope and extent of the impacts from climate variability and change on food production, water resources, and ecosystem health, there is a need to form global partnerships for developing climate-smart agricultural production strategies while minimizing negative impacts on natural resources. For example, the scientific community must work closely with the agricultural industry to develop and adopt crop varieties that could increase crop production under anticipated temperature and precipitation changes. Similarly, irrigation strategies must be developed where crop production is expected to drastically reduce under rainfed conditions. Such efforts will enable us to develop and implement holistic strategies for adapting and mitigating the adverse impacts of climate variability and change as they relate to agricultural production and watershed management.

This Special Collection highlights the fact that agricultural production, water availability, and water quality are going to be substantially impacted by climate change. There are technological options available to mitigate adverse impacts of climate change, but adaptation strategies will require rethinking agricultural management practices to maintain crop and livestock production while protecting environmental quality.

\section{REFERENCES}

Alqudah, A. M., Samarah, N. H., \& Mullen, R. E. (2011). Drought stress effect on crop pollination, seed set, yield and quality. In E. Lichtfouse (Ed.), Alternative farming systems, biotechnology, drought stress and ecological fertilisation (pp. 193-213).

Dordrecht: Springer Netherlands. http://dx.doi.org/10.1007/97894-007-0186-1_6

Anandhi, A., Omani, N. N., Chaubey, I., Horton, R., Bader, D., \& Nanjundiah, R. S. (2016). What changes do the CMIP5 climate models predict for South Asia and what are some potential impacts on managed ecosystems and water resources. Trans. ASABE, 59(6), 1715-1732.

http://dx.doi.org/10.13031/trans.59.11585

Barnabas, B., Jager, K., \& Feher, A. (2008). The effect of drought and heat stress on reproductive processes in cereals. Plant, Cell Environ., 31(1), 11-38.

Barron, J., Rockstrom, J., Gichuki, F., \& Hatibu, N. (2003). Dry spell analysis and maize yields for two semi-arid locations in east Africa. Agric. For. Meteorol., 117(1-2), 23-37. http://dx.doi.org/10.1016/S0168-1923(03)00037-6

Bates, B. C., Kundzewicz, Z. W., Wu, S., \& Palutikof, J. P. (2008). Climate change and water technical paper of the Intergovernmental Panel on Climate Change. 95, 96. Geneva, Switzerland: IPCC Secretariat. Retrieved from http://www.ipcc.ch/pdf/technical-papers/climate-change-wateren.pdf

Bita, C., \& Gerats, T. (2013). Plant tolerance to high temperature in a changing environment: scientific fundamentals and production of heat stress-tolerant crops. Front. Plant Sci., 4(273). http://dx.doi.org/10.3389/fpls.2013.00273

Bonsor, H., MacDonald, A., \& Calow, R. (2011). Potential impact of climate change on improved and unimproved water supplies in Africa. RSC Issues Environ. Sci. Tech., 31, 25-49. http://dx.doi.org/10.1039/9781849732253-00025

Bosch, N. S., Evans, M. A., Scavia, D., \& Allan, J. D. (2014). Interacting effects of climate change and agricultural BMPs on nutrient runoff entering Lake Erie. J. Great Lakes Res., 40(3), 581-589. http://dx.doi.org/10.1016/j.jglr.2014.04.011

Calow, R., \& MacDonald, A. (2009). What will climate change mean for groundwater supply in Africa? London, U.K.: Overseas Development Inst.

Carter, R. C., \& Parker, A. (2009). Climate change, population trends and groundwater in Africa. Hydrol. Sci. J., 54(4), 676689. http://dx.doi.org/10.1623/hysj.54.4.676

Chaubey, I., Chiang, L., Gitau, M. W., \& Mohamed, S. (2010). Effectiveness of best management practices in improving water quality in a pasture-dominated watershed. JSWC, 65(6), 424437. http://dx.doi.org/10.2489/jswc.65.6.424

Delpla, I., Jung, A. V., Baures, E., Clement, M., \& Thomas, O. (2009). Impacts of climate change on surface water quality in relation to drinking water production. Environ. Int., 35(8), 12251233. http://dx.doi.org/10.1016/j.envint.2009.07.001

Garbrecht, J. D., Nearing, M. A., Zhang, J. X. C., \& Steiner, J. L. (2016). Uncertainty of climate change impacts on soil erosion from cropland in central Oklahoma. Appl. Eng. Agric., 32(6), 833-846. http://dx.doi.org/10.13031/appl.32.11613

Hepworth, N., \& Goulden, M. (2008). Climate change in Uganda: Understanding the implications and appraising the response. Edinburgh, U.K.: LTS Int. http://dx.doi.org/10.13031/appl.32.11613

Jacobson, L. D., Auvermann, B. W., Massey, R., Mitloehner, F. M., Sutton, A. L., \& Xin, H. (2011). Air issues associated with animal agriculture: A North American perspective. Council for Agricultural Science and Technology (CAST) Issue Paper 47. Ames, IA: CAST.

Jiménez Cisneros, B. E., Oki, T., Arnell, N. W., Benito, G., Cogley, J. G., Döll, P., ... van den Hurk, B.(2014). Freshwater resources. In Climate change 2014: Impacts, adaptation, and vulnerability. Part A: Global and sectoral aspects. Contribution of Working Group II to the 5th Assessment Report of the Intergovernmental 
Panel on Climate Change (pp. 229-269). Cambridge, U.K.: Cambridge University Press.

Kim, S. H., Myoung, B., Stack, D. H., Kim, J., \& Kafatos, M. C. (2016). Sensitivity of maize yield potential to regional climate in the southwestern United States. Trans. ASABE, 59(6), 17451757. http://dx.doi.org/10.13031/trans.59.11584

Kundzewicz, Z. W., \& Döll, P. (2009). Will groundwater ease freshwater stress under climate change? Hydrol. Sci. J., 54(4), 665-675. http://dx.doi.org/10.1623/hysj.54.4.665

Kundzewicz, Z. W., Mata, L. J., Arnell, N. W., Doll, P., Kabat, P., Jiménez, B.,... Shiklomanov, I. A. (2007). Freshwater resources and their management. In M. L. Parry, O. F. Canziani, J. P. Palutikof, P. J. van der Linden, \& C. E. Hanson (Eds.), Climate change 2007: Impacts, adaptation, and vulnerability. Contribution of Working Group II to the 4th Assessment Report of the IPCC. Cambridge, U.K.: Cambridge University Press.

Lema, M. A., \& Majule, A. E. (2009). Impacts of climate change, variability and adaptation strategies on agriculture in semi arid areas of Tanzania: The case of Manyoni District in Singida Region, Tanzania. Afr. J. Environ. Sci. Technol., 3(8), 206-218.

Lobell, D. B., \& Gourdji, S. M. (2012). The influence of climate change on global crop productivity. Plant Physiol., 160(4), 1686-1697. http://dx.doi.org/10.1104/pp.112.208298

Mongi, H., Majule, A. E., \& Lyimo, J. G. (2010). Vulnerability and adaptation of rain fed agriculture to climate change and variability in semi arid Tanzania. Afr. J. Environ. Sci. Technol., 4(6), 371-381. https://doi.org/10.5897/AJEST09.207

Myoung, B., Kim, S. H., Kim, J., \& Kafatos, M. (20156). Regional variations of optimal sowing dates of maize for the southwestern United States. Trans. ASABE, 59(6), 1759-1769. http://dx.doi.org/10.13031/trans.59.11583

Nearing, M. A., Pruski, F. F., \& O’Neal, M. R. (2004). Expected climate change impacts on soil erosion rates: A review. JSWC, 59(1), 43-50. Retrieved from http://www.jswconline.org/content/59/1/43.abstract

Oliver, J. P., \& Schilling, J. S. (2016). Capture of methane by fungi: Evidence from lab-scale biofilter and chromatographic isotherm studies. Trans. ASABE, 59(6), 1791-1801. http://dx.doi.org/10.13031/trans.59.11595

Paavola, J. (2008). Livelihoods, vulnerability and adaptation to climate change in Morogoro, Tanzania. Environ. Sci. Policy, 11(7), 642-654. http://dx.doi.org/10.1016/j.envsci.2008.06.002

Parry, M. L., Canziani, O. F., Palutikof, J. P., van der Linden, P. J., \& Hanson, C. E. (Eds.). (2007). Climate change 2007: Impacts, adaptation and vulnerability. Contribution of Working Group II to the 4th Assessment Report of the Intergovernmental Panel on Climate Change. Cambridge, U.K.: Cambridge University Press.

Porter, J. R., Xie, L., Challinor, A. J., Cochrane, K., Howden, S. M., Iqbal, M. M.,... Travasso, M. I. (2014). Food security and food production systems. In C. B. Field, V. R. Barros, D. J. Dokken, K. J. Mach, M. D. Mastrandrea, T. E. Bilir,... L. L. White (Eds.), Climate change 2014: Impacts, adaptation, and vulnerability. Part A: Global and sectoral aspects. Contribution of Working Group II to the 5th Assessment Report of the Intergovernmental Panel on Climate Change (pp. 485-533). Cambridge, U.K. and New York, NY,: Cambridge University Press.

Renkenberger, J., Montas, H., Leisnham, P., Chanse, V., Shirmohammadi, A., Sadeghi, A.,... Lansing, D. (2015). Effectiveness of best management practices with changing climate in a Maryland watershed. Proc. ASABE 1st Climate Change Symp.: Adaptation and Mitigation Conf. (pp. 1-3). St. Joseph, MI: ASABE. http://dx.doi.org/10.13031/cc.20152122791
Renkenberger, J., Montas, H., Leisnham, P., Chanse, V., Shirmohammadi, A., Sadeghi, A.,... Lansing, D. (2016). Climate change impact on critical source area identification in a Maryland watershed. Trans. ASABE, 59(6), 1803-1819. http://dx.doi.org/10.13031/trans.59.11677

Resende, N. C., Miranda, J. H., Chou, S. C., \& Cooke, R. A. (2016). Regional climate changes on drain-age systems: Effects on corn productivity and profitability in Campinas, Brazil. Trans. $A S A B E, 59(6), 1783-1790$. http://dx.doi.org/10.13031/trans.59.11588

Rotz, C. R., Skinner, R. H., Stoner, A. M. K., \& Hayhoe, K. (2016). Evaluating greenhouse gas miti-gation and climate change adaptation in dairy production using farm simulation. Trans. ASABE, 59(6), 1771-1781. http://dx.doi.org/10.13031/trans.59.11594

Sharda, V., \& Srivastava, P. (2016). Value of ENSO-forecasted drought information for the management of water resources of small to mid-size communities. Trans. ASABE, 59(6), 17331744. http://dx.doi.org/10.13031/trans.59.11589

Sheshukov, A. Y., Siebenmorgen, C. B., \& Douglas-Mankin, K. R. (2011). Seasonal and annual impacts of climate change on watershed response using an ensemble of global climate models. Trans. ASABE, 54(6), 2209-2218.

http://dx.doi.org/10.13031/2013.40660

Solomon, S., Qin, D., Manning, M., Chen, Z., Marquis, M., Averyt, K. B.,... Miller, H. L. (Eds.). (2007). Climate change 2007: The physical science basis. Contribution of Working Group I to the 4th Assessment Report of the Intergovernmental Panel on Climate Change. Cambridge, U.K.: Cambridge University Press.

Stone, P. (20001). The effects of heat stress on cereal yield and quality. In A. S. Basra (Ed.), Crop responses and adaptations to temperature stress (pp. 243-291). Binghamton, NY: Food Products Press.

Taylor, R. G., Scanlon, B., Doll, P., Rodell, M., van Beek, R., Wada, Y.,... Treidel, H. (2013). Ground water and climate change. Nature Clim. Change, 3(4), 322-329. http://dx.doi.org/10.1038/nclimate1744

USGS. (2015). What are stormwater best management practices? Reston, VA: USGS. Retrieved from http://egsc.usgs.gov/1stormwater_bmp.html

Walsh, J., Wuebbles, D., Hayhoe, K., Kossin, J., Kunkel, K., Stephens, G.,... Somerville, R. (2014). Ch. 2: Our changing climate. Climate change impacts in the United States: The 3rd national climate assessment. In J. M. Melillo, T. C. Richmond, \& G. W. Yohe (Eds.), U.S. Global Change Research Program (pp. 19-67). Retrieved from http://nca2014.globalchange.gov.

Werner, A. D., Ward, J. D., Morgan, L. K., Simmons, C. T., Robinson, N. I., \& Teubner, M. D. (2012). Vulnerability indicators of sea water intrusion. Ground Water, 50(1), 48-58. http://dx.doi.org/10.1111/j.1745-6584.2011.00817.x

Woznicki, S. A., \& Nejadhashemi, A. P. (2012). Sensitivity analysis of best management practices under climate change scenarios. JAWRA, 48(1), 90-112. http://dx.doi.org/10.1111/j.17521688.2011.00598.x

Woznicki, S. A., \& Nejadhashemi, A. P. (2014). Assessing uncertainty in best management practice effectiveness under future climate scenarios. Hydrol. Process., 28(4), 2550-2566. http://dx.doi.org/10.1002/hyp.9804

Woznicki, S. A., Nejadhashemi, A. P., \& Smith, C. M. (2011). Assessing best management practice implementation strategies under climate change scenarios. Trans. ASABE, 54(1), 171-190. http://dx.doi.org/10.13031/2013.36272 